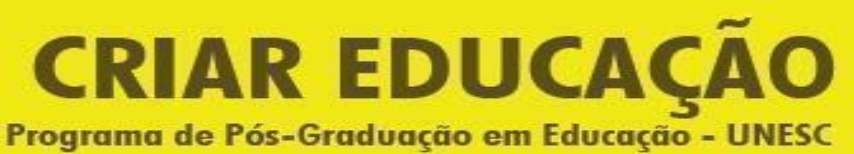

Revista do Programa de Pós-Graduação em Educação - UNESC

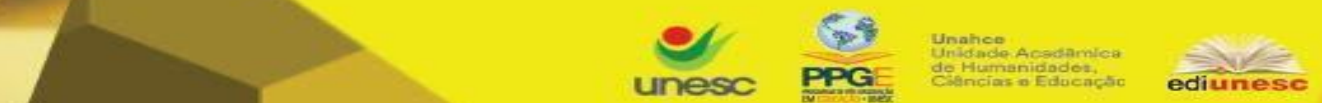

Criar Educação, Criciúma, v. 9, № 3, ago/dez. 2020 - PPGE - UNESC - ISSN 2317-2452

\title{
ARTE, ESCOLA E ENSINO: REFLEXÕES A PARTIR DO PENSAMENTO DE NIETZSCHE
}

\author{
Celio Roberto Eyng ${ }^{1}$
}

Resumo: O presente artigo discute a relação entre arte, escola e ensino com o objetivo de produzir reflexões a partir do pensamento de Nietzsche. Para isso, produziu-se uma revisão bibliográfica de sua obra, a qual envolveu a análise textual tanto dos escritos que tratam especificamente da arte, quanto de temáticas afins, como a linguagem, a consciência e o jogo da criação. Após o estudo dos excertos selecionados, iniciou-se o estabelecimento de correlações entre o repertório conceitual nietzschiano e suas implicações para se pensar a constituição do arte-educador, a finalidade da arte na educação e no ensino escolar e as especificidades do ensino da arte na escola. A perspectiva trágica, defendida por Nietzsche, possibilitou repensar as relações entre arte, escola e ensino e entre arte, ciência e linguagem, reafirmando a arte como o grande estimulante da vida escolar.

Palavras-chave: Nietzsche; ensino da arte; arte-educação; ensino escolar.

\section{ART, SCHOOL AND TEACHING: REFLECTIONS FROM NIETZSCHE'S THOUGHT}

\begin{abstract}
This article discusses the relationship between art, school and teaching in order to produce reflections based on Nietzsche's thought. For this, a bibliographic review of his work was produced, which involved the textual analysis of both the writings that deal specifically with art, and related themes, such as language, conscience and the game of creation. After studying the selected excerpts, correlations between the Nietzschean conceptual repertoire and its implications for thinking about the constitution of art-educator, the purpose of art in education and school education, and the specificities of art teaching in school. The tragic perspective, defended by Nietzsche, made it possible to rethink the relations between art, school and teaching and between art, science and language, reaffirming art as the great stimulant of school life.
\end{abstract}

Keywords: Nietzsche; art teaching; art education; school education.

\footnotetext{
1 Professor adjunto no Curso de Pedagogia da Universidade Estadual do Oeste do Paraná (UNIOESTE) - campus de Francisco Beltrão. Endereço: Centro de Ciências Humanas. Rua Maringá, 1200 Bairro Vila Nova Francisco Beltrão PR CEP 85605-010 e-mail: celioeyng@hotmail.com
} 


\section{Introdução}

No presente artigo apresentamos uma discussão acerca da relação entre arte, escola e ensino. O objetivo da nossa pesquisa foi produzir reflexões sobre a finalidade da arte e do ensino da arte no contexto escolar a partir do pensamento de Nietzsche. Para isso, realizamos uma revisão bibliográfica da obra desse autor, buscando averiguar sua compreensão acerca do fenômeno artístico. Também, investigamos temáticas afins ao objeto em foco, como a linguagem, a consciência e o jogo da criação. Após uma leitura preliminar de uma amostra da bibliografia de Nietzsche $(2005 ; 2007 ; 2012 ; 2017 ; 2018)$, selecionamos excertos que melhor se ajustavam ao nosso propósito. Na sequência, elaboramos textos que analisavam as seguintes relações: arte como criação; forças apolíneas e dionisíacas; arte e linguagem; cultura teórica e cultura trágica. A análise dessas relações subsidiou a discussão sobre a finalidade da arte na educação e no ensino escolar e as especificidades do arte-educador e do ensino da arte no contexto escolar.

O artigo está organizado em itens dispostos na seguinte sequência: o camelo, o leão e a criança; arte como criação; forças apolíneas e dionisíacas; arte e linguagem; a finalidade da arte na educação; a finalidade da arte no ensino escolar; o arte-educador e a especificidade do ensino da arte; considerações finais e referências.

\section{O camelo, o leão e a criança}

No primeiro dos discursos de Zaratustra, Nietzsche (2018, p. 43) propõe a parábola das três transformações: "como o espírito se torna camelo, o camelo leão, e, por fim, como o leão se torna criança". De início, o espírito necessita lidar com o pesado. Para isso, ele se torna camelo; sob a insígnia do "eu devo", o espíritocamelo reverencia o peso da tradição. Porém, para enfrentar o dragão do "eu devo" e suas escamas de valores milenares, o espírito-camelo precisa passar por uma segunda transformação: tornar-se leão. Na solidão do deserto, o leão, como animal predador que é, reclama para si a liberdade de "dizer um não" à obrigação. Mas por mais que ele seja capaz de exercitar a liberdade do "eu quero", não está apto a 
inventar seus próprios valores. Para esse fim, é necessário que o espírito passe pela terceira transformação: torne-se criança. A criança, tal qual uma roda que gira a partir de si mesma, movimenta-se em prol de um "viver a vida de corpo inteiro". Para a criação de novos valores é mister que o espírito-criança, embriagado pela insígnia de um sagrado "dizer sim", esteja completamente absorto no jogo criativo.

Gostaríamos de iniciar nossas reflexões acerca da relação entre arte, escola e ensino a partir de uma interpretação das metáforas utilizadas por Nietzsche (2018). Nas areias do deserto o camelo é utilizado como animal de carga. Sua incumbência é transportar as pessoas e seus pertences. À imagem do camelo associamos o imperativo "eu devo". E essa imagem do camelo é sintomática: nós, arte-educadores, carregamos o peso das tradições artística e pedagógica em nossas costas. De que maneira teríamos aprendido conceitos artísticos ou desenvolvido habilidades específicas sem submetermo-nos às tradições culturais instituídas, suas regras e convenções, suas maneiras de proceder e saberes específicos? O espírito-camelo não é, necessariamente, bom ou ruim, apenas uma condição: cada um de nós carrega o peso das tradições culturais com as quais familiarizou-se em sua vida.

O arte-educador, no contexto escolar, não pode eximir-se da condição de ser espírito-camelo. Ademais, ele assume uma função ainda mais interessante: torna-se um representante das tradições artísticas e pedagógicas. Para que o aprendizado artístico se efetive, a intervenção pedagógica não poderá abrir mão de traçar metas, estabelecer prazos e procedimentos e atribuir conceitos ou notas. A insígnia do espírito-camelo é persuasiva e, por mais avesso que o arte-educador seja à burocracia ou à imposição de valores, lá estará ele executando o programa curricular e, de maneira inevitável, contribuindo para que o peso das tradições afete os corpos de seus alunos.

Mas não somente como espírito-camelo o ser humano plasma sua existência. A segunda transformação que Zaratustra relata diz respeito à mudança do espíritocamelo para espírito-leão. Assim, para enfrentar o dragão da obrigação e livrar-se de suas escamas milenares, o espírito necessita assumir outra incumbência - a insígnia do "eu quero". Para representar essa atitude Nietzsche utilizou a imagem do 
leão. O felino, um autêntico predador, diz "eu quero" ao seu instinto. Assim, o rei da selva, como costumeiramente é conhecido, simboliza o direito à liberdade e a negação da tradição. $\mathrm{E}$ à metáfora do leão relacionamos 0 desejo de autodeterminação do arte-educador na escola. Como um leão que demarca o seu território, ele busca delimitar seu espaço no ambiente escolar. O ambiente, por vezes, é inóspito, mas o arte-educador almeja o reconhecimento pela singularidade de sua área de atuação. O espírito-leão contrapõe-se aos valores instituídos e deseja construir seus próprios valores. De maneira análoga, ele refuta saberes e práticas com os quais não concorda. Assim, intencionamos fazer as coisas à nossa maneira. Todavia, não somos somente nós, os arte-educadores, regidos pela insígnia do "eu quero": os alunos, colegas de trabalho e diretores também plasmam a sua existência por essa via. Assim, o espírito-leão e o espírito-camelo transmutamse incessantemente nas relações interpessoais.

As insígnias do "eu devo" e do "eu quero" não são suficientes para que o jogo da criação aconteça. O peso da tradição é intrínseco ao processo de humanização, mas não basta dizer "eu quero" para que o jogo da criação se desenrole. Por isso, para que novos valores possam ser criados é necessária uma terceira transformação: o espírito precisa tornar-se criança. É sintomática a escolha da criança como símbolo do jogo da criação. A infância, como a primeira etapa na vida do ser humano, constitui-se em um momento cercado de cuidados e de dependência em relação aos adultos. Por sua vez, nos jogos da infância, a criança emprega toda sua força e plenitude. Absorta na atividade lúdica, em diferentes momentos de sua vida, a criança entrega-se por completo nas ações que realiza. $E$ essa entrega intensa e plena na realização de algo é vista, por Nietzsche (2018), como uma condição necessária ao jogo da criação.

\section{Arte como criação}

Nós, seres humanos, quando pensamos acerca das manifestações artísticas, consideramo-las criações - formas produzidas a partir da utilização de uma técnica ou de um conjunto de procedimentos técnicos e habilidades específicas. O conceito 
de arte como criação humana transcende o escopo restrito das produções tipicamente artísticas (a música, o teatro, as artes visuais, a dança, o cinema etc.). Por essa via, generaliza-se o conceito de arte como criação para se pensar as mais variadas atividades humanas como a arte de dominar o fogo, a arte da caça e da pesca, a arte da culinária, o futebol-arte ou a arte da criança "arteira", entre tantas outras generalizações possíveis.

O conceito de arte como criação foi amplamente teorizado pelos gregos na Antiguidade Clássica. Na mitologia grega é atribuído a Prometeu o roubo do fogo sagrado e a transmissão aos seres humanos do conhecimento das diferentes artes e ciências. Nesse contexto, arte significava techné, ou seja, o conjunto de procedimentos técnicos utilizados na produção de artefatos ou no desenvolvimento de habilidades como a arte política, médica ou retórica. Por esse viés, o conhecimento racional das técnicas utilizadas na produção de algo ou no desenvolvimento de habilidades específicas é considerado o marco que diferencia os seres humanos dos demais animais.

Embora o conceito de arte, especificamente como criação humana, seja contundente, não podemos nos esquecer que outras espécies de animais também produzem seus artefatos e desenvolvem habilidades específicas. Assim, apreciamos a beleza da teia tecida por uma aranha, a dança de acasalamento dos pavões e a capacidade arquitetônica do joão-de-barro. Tais habilidades artísticas instintivas, observáveis nas diversas espécies de animais, apontam para a importância de se compreender a arte como uma atividade criadora permeada não somente pelo espírito-camelo, ou seja, pelo peso da tradição cultural, mas como um processo embotado de impulsos naturais.

\section{Forças apolíneas e dionisíacas}

Em diferentes momentos de sua obra filosófica, Nietzsche discute as tradições culturais relacionadas à arte. Todavia, o filósofo também disserta acerca dos impulsos naturais envolvidas na criação artística. Na obra "O nascimento da tragédia ou Helenismo e Pessimismo", Nietzsche (2007) analisa o surgimento do 
teatro trágico grego na Antiguidade Clássica. Ao compreender o desenvolvimento da arte trágica como a contraposição entre forças apolíneas e dionisíacas, Nietzsche utiliza-se de uma interpretação muito peculiar sobre a mitologia helênica: as forças da criação artística estariam atreladas às condições fisiológicas dos seres vivos - 0 sono e o sonho, ligados à Apolo, e a embriaguez, relacionada a Dionísio.

Por meio das forças apolíneas o ser humano configura belas formas para atribui sentido à vida e ao mundo. O sono e o sonho, como estados fisiológicos que reconfortam o ser humano, são interpretados como exemplos da bela aparência, as quais se contrapõem à vida cotidiana, por vezes pouco inteligível. Assim, as forças apolíneas estariam relacionadas ao surgimento das artes plásticas e de uma parte importante da poesia, quando essa evoca, em nossas mentes, por meio de palavras e conceitos, imagens de locais, acontecimentos, pessoas, emoções e sentimentos etc.

Nietzsche (2007) afirma que o nascimento da tragédia ática é obra da contraposição contínua entre as forças apolíneas e as forças dionisíacas, das quais a música, uma arte não figurativa - haja vista os sons musicais não serem visíveis nem palpáveis -, é considerada seu principal exemplo. Por essa via explicativa, o filósofo diz que a embriaguez dionisíaca envolve a intensificação das forças da natureza e o seu consequente esvanecimento do subjetivo pelo auto-esquecimento, o que significa dizer que, com o canto e a dança, imerso no ritmo musical e imbuído pela embriaguez dionisíaca, o ser humano já não é mais um artista, ou seja, um produtor de artefatos artísticos, mas torna-se uma obra de arte, reconciliando-se com as forças da natureza.

No livro "Crepúsculo dos ídolos, ou, como se filosofa com o martelo", quando discute acerca da psicologia do artista, Nietzsche (2017) retoma a temática da embriaguez para enfatizar seus aspectos fisiológicos. Para o filósofo, a embriaguez é uma condição fisiológica necessária para que a criação e a contemplação artísticas ocorram. Nietzsche (2017) considera que somente por meio do sentimento de plenitude - o que pode ser interpretado como o envolvimento de corpo inteiro da pessoa na realização de algo -, e da intensificação da força, ou seja, a exacerbação das potencialidades do indivíduo na efetivação de uma atividade, a criação artística 
e o contemplar estético podem existir. Sobre isso, o autor complementa dizendo que "o homem que se encontra nesse estado transforma as coisas até que reflitam o seu poder - até que sejam reflexos de sua perfeição. Esse ter de transformar em perfeição é - arte (idem, p. 83, itálico no original)".

Podemos interpretar que, na obra de Nietzsche, a arte é compreendida como um fenômeno estético que intensifica a vida, atribuindo-Ihe sentido. Aliada a essa ideia está a noção de que o ser humano precisa tornar-se uma obra de arte, ou seja, deve mobilizar suas forças para plasmar o mundo com sua existência. Nesse perspectiva, o conceito de arte como criação não exclui os impulsos naturais, como as condições fisiológicas que constituem nossos corpos, e que estão imbricados na interação do ser humano com o ambiente.

\section{Arte e linguagem}

De maneira inevitável, utilizaremos palavras e conceitos para atribuir sentido aos processos naturais e culturais envolvidos na criação artística. As palavras e seus significados, os conceitos, constituem-se sistemas simbólicos de significação que possibilitam atribuir sentido à arte. O processo de significação não se restringe à linguagem verbal, mas de que maneira poderíamos nos comunicarmos, nesse momento, sem o seu uso? Utilizamo-nos da linguagem verbal para analisarmos os diferentes aspectos envolvidos na criação e contemplação de formas artísticas, cientes de que ela não será capaz de traduzir a experiência estética em sua inteireza. Por isso, consideramos que, de maneira diversa à linguagem, a arte visa ao inominável e ao inefável.

Em A Gaia Ciência, quando discute o surgimento da consciência no ser humano, Nietzsche (2012) entende a linguagem como uma rede de relações entre pessoas que torna viável a comunicação e, como tal, sua marca é constituir-se "consciência de rebanho", isto é, uma construção social relacionada à natureza gregária dos seres humanos. Na obra "Crepúsculo dos ídolos, ou, como se filosofa com o martelo", Nietzsche (2017) reafirma sua desconfiança em relação à 
linguagem, considerando que as experiências mais importantes da vida não são tagarelas.

Consideramos que a desconfiança de Nietzsche para com à linguagem é de especial importância para refletirmos acerca da relação entre arte, escola e ensino. Acreditamos que um grande desafio para os arte-educadores tem sido 0 planejamento, implementação e avaliação de intervenções pedagógicas que consigam estabelecer correlações entre o aprendizado dos conceitos artísticos e a realização de procedimentos de criação e contemplação de formas artísticas. _Como evitar que as aulas de arte tornem-se "tagarelas", centradas na fala e na escrita? Essa é uma questão que o arte-educador precisa prestar especial atenção. $\mathrm{Na}$ medida em que a arte tornou-se uma área de conhecimento no ensino escolar, enfrentamos o dilema de ensinar conceitos artísticos que, por vezes, transformam-se em sequências didáticas voltadas à leitura e à escrita. Aliar a aprendizagem conceitual com a realização de atividades de criação e fruição artísticas constitui-se um problema teórico e metodológico. Mais adiante, retomaremos esse problema. Por ora, analisemos mais uma relação entre arte e linguagem: a utilização da linguagem como matéria-prima na criação artística.

A linguagem funciona como matéria-prima para a arte, seja na criação especificamente literária, seja nas suas imbricações com a música, o teatro e o cinema, por exemplo. Em "Humano Demasiado Humano", quando discute acerca da criação poética, Nietzsche (2005) destaca os efeitos da métrica. Para ele, o ritmo da música afeta a criação poética, tornando as palavras e conceitos mais vagos. Em "A Gaia Ciência”, Nietzsche (2012) ressalta que a origem da poesia está relacionada com o poder do ritmo musical. Nos povos da antiguidade, com o uso da métrica rítmica, as funções utilitária e comunicacional da linguagem são ampliadas para a comunicação com os deuses, para acalma-los ou excita-los; também, ela têm a finalidade de apaziguar o sofrimento da alma e de contribuir na realização dos diferentes trabalhos cotidianos.

A partir da análise dos apontamentos de Nietzsche, entendemos que a relação entre arte e linguagem se constitui um paradoxo: na medida em que a linguagem tornou-se, no desenvolvimento da espécie, a principal forma de 
comunicação entre os seres humanos e uma parte importante de seus processos mentais conscientes, ela também vulgariza-se, assumindo uma tendência de reproduzir a natureza gregária da espécie humana, isto é, os valores e crenças de uma tradição cultural específica. Todavia, quando a linguagem flerta com o ritmo musical e explora imagens, gestos e cenas, ou seja, nutre-se da métrica rítmica e do poder da imaginação simbólica, ela torna-se uma modalidade de criação artística. Ao assumir a forma poética ou transformar-se em prosa, enredo teatral ou roteiro cinematográfico, os significados do texto verbal são embebidos pelo véu do pensamento impuro (NIETZSCHE, 2005). E ali, nesse contexto, a linguagem não está mais incumbida, tão somente, das funções utilitária e comunicacional, mas assume uma função estética - aquela que envolve a excitação da "máquina inteira" (NIETZSCHE, 2017).

\section{A finalidade da arte na educação}

A educação pode ser compreendida como a transmissão, de geração em geração, dos saberes e práticas de uma tradição cultural. Em cada contexto histórico-cultural a arte é produzida e apreciada, mas também ensinada e aprendida de diferentes maneiras: pela convivência em uma família ou comunidade; de forma autodidata; por meio da relação entre o mestre de ofício e seus aprendizes; ou em academias, conservatórios, ateliês e companhias especializadas. Assim, a relação entre arte e educação se efetiva em diferentes âmbitos da vida social, como na família, nas atividades laborais, no mercado de bens simbólicos e na escola.

A escola, como a conhecemos na atualidade, é uma criação da modernidade. Na sua constituição, buscou-se a organização sistemática do tempo e do espaço em turmas seriadas e disciplinas de estudo específicas, a profissionalização docente e o desenvolvimento de métodos de ensino e de avaliação direcionados à aplicação em grupos de alunos. Por meio do ensino escolar, as futuras gerações se apropriam de parte dos sistemas simbólicos de uma tradição cultural ou, geralmente, de um emaranhado de tradições culturais relacionados à arte, à ciência, à filosofia e à religião. Por isso, a seleção de quais saberes e práticas farão parte do currículo 
escolar é uma questão tipicamente política, ou seja, pressupõe o exercício da governança em uma população ou grupo social e, por isso, está implicada pelas relações de poder (TADEU, 2011).

Nos escritos dos filósofos-legisladores da Antiguidade Clássica, especialmente Platão e Aristóteles, a discussão acerca da finalidade da arte na educação era um problema de Estado. Para Platão (1997), a constituição de uma cidade ideal envolveria a definição de quais seriam os conhecimentos ensinados para os futuros guerreiros e aqueles que deveriam ser evitados. Ao discutir sobre 0 compromisso da arte com a verdade e a moral, o filósofo considerava que os poetas, por vezes, imitavam os vícios e não as virtudes. Assim, o legislador censurava os poetas e, de uma forma geral, todas as artes que imitavam valores morais inapropriados - elas não seriam úteis à formação do guerreiro e deveriam ser banidas da formação dos cidadãos livres.

Na concepção de Platão (1997), a música e a ginástica seriam os pilares da educação. Em um trecho de "A República", Sócrates - o protagonista do livro discute com Glauco, que é músico, quais harmonias seriam úteis na formação do guerreiro. Dentre tantas harmonias, restam somente a dórica e a frígia: as demais harmonias imitariam valores inapropriados, como a embriaguez, a moleza e a indolência. Nesse contexto, a harmonia e o ritmo devem ser subordinadas à palavra - aos textos que incitam a virtude e a verdade.

Na visão socrática e platônica, os poetas e músicos devem introduzir em suas criações somente a imagem do bom caráter. Os jovens devem imitar, desde a infância, o reto e o razoável, e amar as obras belas que relacionam-se com o bom e o verdadeiro. $\mathrm{E}$ para isso são úteis dois tipos de harmonias: aquela que favorece a ação violenta, como a do soldado na batalha; e aquela que incite uma ação voluntária, voltada à persuasão dos homens e dos deuses.

Aristóteles, assim como Platão, elegeu a educação como um tema importante em seus escritos. No livro "A Política", o filósofo legislou acerca da educação dos jovens atenienses, discutindo o papel do Estado na organização do ensino e quais conhecimentos precisariam ser ensinados. Aristóteles (2003) se perguntava se era conveniente ensinar apenas o que é útil. Desde o período arcaico, a gramática, a 
ginástica e a música, e por vezes o desenho, eram os principais conhecimentos ensinados entre os gregos. O filósofo propõe que a educação deve preocupar-se não somente com o trabalho, mas também com o tempo livre. A música, para Aristóteles, deve ser ensinada por dois motivos: porque ela é útil nas horas de repouso e porque imita os reais sentimentos da alma. Por isso, os jovens não devem só aprecia-la, mas aprender a manipula-la.

A teoria da imitação - mímesis - defendida por Aristóteles e Platão, diz respeito à ideia de que a arte imita a vida. Nesse sentido, as artes em geral e a música, em específico, têm o poder de imitar os sentimentos mais variados, como a ira, a cólera, a doçura, a audácia, a temperança etc. Por isso, a arte precisa ser utilizada na educação para que os futuros cidadãos gregos aprendam a imitar os valores morais apropriados desde a infância. Assim, desde muito cedo, a música, por exemplo, deve ser introduzida não só nas horas de lazer, porque sua prática é prazerosa, mas também como recurso pedagógico, pois torna-se um veículo de transmissão da tradição cultural helênica. Mas qual tradição cultural Platão e Aristóteles desejavam perpetuar com a arte?

Para responder a essa pergunta precisamos retomar um assunto abordado anteriormente: a ideia, introduzida por Nietzsche, de que as forças apolíneas e dionisíacas são responsáveis pelo surgimento da tragédia na Grécia Antiga. Para Nietzsche (2007), as forças apolíneas, as quais têm como análogo o sono e o sonho, estão relacionadas com a bela aparência. A criação nas artes plásticas e boa parte da poesia envolveria o predomínio das forças apolíneas. Assim, o ser humano produz imagens e pensa com conceitos, construindo formas visuais que agradam os olhos e versos ritmados com palavras que visam cultuar o bom e o verdadeiro. Apolo representa o autoconhecimento e, para aqueles que desejam contemplar a vida com mais clareza, as belas imagens e as palavras bem articuladas são afins ao "conhece-te a ti mesmo" e à temperança - "nada em demasia" (NIETZSCHE, 2007, p. 37).

Nietzsche (2007) interpreta que Platão e Aristóteles, como discípulos de Sócrates, preconizam que a educação dos jovens deve basear-se na utilização das forças apolíneas. Para os gregos, no período clássico, Apolo representava a 
emergência da civilização helênica em detrimento da era dos Titãs e da época préapolínea - o mundo dos bárbaros. Nesse contexto, a valorização das forças apolíneas está relacionada com a ideia de que o processo civilizatório está engendrado pelo pensamento racional e pela busca do autoconhecimento. Decorre dessa premissa a noção de que os poetas devem imitar somente os valores morais apropriados à constituição do caráter dos jovens. Aprender a amar o bom, o belo e o verdadeiro exige a clareza no raciocínio e o reconhecimento dos símiles do bom, do belo e do verdadeiro na vida cotidiana.

No tocante à finalidade da música na educação pelo viés socrático, as forças apolíneas devem se sobressair às forças dionisíacas, o que significa dizer que os sons musicais precisam subordinar-se à linguagem; e que as palavras devem fomentar a virtude e a temperança, e não o vício e o descomedimento. Por esse viés, o poder dionisíaco da música não pode sobressair-se, ou seja, sua capacidade de arrebatar o corpo por inteiro e de dissipar os significados da palavra deve ser controlado. Assim, a concepção socrática, levada adiante por Platão e Aristóteles, entende que os instrumentos musicais dionisíacos devem ser banidos da educação, bem como as harmonias estrangeiras ou aquelas que incitam valores morais inapropriados na formação do cidadão grego.

O poder da música de imitar os "reais sentimentos da alma", como nos falam os filósofos-legisladores, precisa estar a serviço da perpetuação de uma tradição cultural "que acredita em uma correção do mundo pelo saber, em uma vida guiada pela ciência" (NIETZSCHE, 2007, p. 105). A essa tradição cultural Nietzsche cunhou o termo "cultura teórica". Para Nietzsche (2007), o otimismo socrático de que o autoconhecimento, guiado pela razão, pode ser o principal instrumento no melhoramento do ser humano, constitui-se o protótipo de uma cultura teórica que valoriza a ciência em detrimento da arte e que tem como ideal de homem o "homem teórico" (idem, p. 106; itálico no original). A crença socrática de que os mitos poderiam ser substituídos pelo logos, isto é, pela descoberta de leis universais a partir do pensamento humano, inscreve-se na modernidade e em seus meios educativos como se a única existência digna de existir fosse a cultura teórica. 
No entanto, na posição de Nietzsche (2007), filósofos como Kant e Schopenhauer denunciaram os limites do pensamento humano no desvelamento da realidade. Para o autor, esses pensadores introduziram na modernidade 0 arcabouço de uma "cultura trágica", ou seja, a noção de que a racionalidade não é suficiente para desvelar os mistérios da existência. Por isso, Nietzsche propõe que, para o homem trágico, a sabedoria deve suplantar a ciência. A cultura trágica, para Nietzsche (2007), está relacionada com a ideia de que a vida não pode ser reduzida, em sua inteireza, aos princípios da lógica, à busca de causas e consequências da ciência e ao crivo do pensamento racional. Por essa via, o filósofo identifica o nascimento da tragédia entre os gregos como o protótipo da cultura trágica, aquela que aceita a crueldade natural das coisas como uma condição inalienável da existência. E uma das características da cultura trágica é a valorização da arte como o grande estimulante da vida.

Para que possamos apontar as diferentes implicações do pensamento de Nietzsche para se pensar a finalidade da arte no ensino escolar, recorremos a mais um tópico importante abordado pelo filósofo: acerca da finalidade da arte. Nas concepções socrática, platônica e aristotélica, a arte está subordinada à moral. No decorrer da história universal, nos mais diferentes contextos culturais e etnias, a arte foi e continua sendo utilizada para o melhoramento do ser humano. Por sua vez, a ideia de que a criação artística não deve estar atrelada aos valores morais é bem mais recente: somente no século XVIII surgem pensadores que buscaram desvencilhar o artista da incumbência de veicular preceitos religiosos, políticos e cívicos em suas produções. Essa posição estética, conhecida como l'art pour l'art, conforme discute Nietzsche (2017, p. 95), envolve "a luta contra a tendência moralizante na arte, contra a sua subordinação à moral”. Todavia, para o filósofo, "quando se exclui da arte a finalidade da pregação moral e do melhoramento do homem, ainda falta muito para se concluir que a arte seja algo sem finalidade, sem meta, sem sentido (...)" (idem, p. 95). Doravante, ele afirma que a concepção da "arte pela arte", ou seja, a luta contra a finalidade moral da arte, não pode ser generalizada para a noção de que a arte não tem nenhuma finalidade. 
Podemos generalizar a posição de Nietzsche (2017), acerca da finalidade da arte, em geral, para pensar a finalidade da arte na educação: a arte pode fortalecer ou enfraquecer certas valorações morais. Assim, se quisermos valorar as forças apolíneas, como os filósofos-legisladores gregos, a arte torna-se um recurso pedagógico valioso na promoção de uma cultura teórica, na qual a arte está subordinada à linguagem. Mas se imaginarmos a finalidade da arte na educação a partir de uma perspectiva trágica, a embriaguez dionisíaca excitaria a "máquina inteira". Por esse viés, a música não seria valorizada apenas como um recurso pedagógico para a inculcação de valores morais. A arte musical, seja aliada à dança, à poesia, ao teatro e às artes visuais, seja estritamente voltada à manipulação dos sons, tornar-se-ia porta-voz dos saberes e práticas que transcendem os significados construídos prioritariamente pela linguagem.

\section{A finalidade da arte no ensino escolar}

Para pensar as implicações do pensamento de Nietzsche acerca da relação entre arte, escola e ensino, analisemos algumas funções principais que a arte assume no ensino escolar. De início, pensemos que a finalidade da arte, conforme aborda Nietzsche (2017), consiste em que ela pode fortalecer ou enfraquecer certas valorações morais. $E$ no contexto escolar não tem sido diferente. $A$ arte, em suas diferentes modalidades (visual, musical, literária, teatral etc.), visa fortalecer os valores morais cultuados pela tradição - estreitar os laços da convivência social, incitar o respeito pelos colegas, professores e símbolos pátrios, celebrar as datas comemorativas, exaltar as atitudes adequadas e exortar os mal exemplos. A canção, por exemplo, com o seu efeito coercitivo provocado pela junção entre ritmo, melodia e linguagem, tem sido utilizada tanto para apaziguar os ânimos - acalmar as crianças para a hora do estudo, a hora do lanche, a hora da oração, a hora da fila etc., quanto para enfatizar os valores da amizade, do respeito ao próximo, do cuidado com o meio ambiente, do cuidado de si mesmo etc. E nas horas de lazer, descanso ou confraternização a arte também mostra-se útil: desenho e literatura para ocupar os alunos que já terminaram a tarefa; música e dança para os 
momentos de festa e júbilo; teatro e poesia para homenagear pais, alunos e professores ou para valorizar os símbolos nacionais e datas importantes.

A finalidade da arte no contexto escolar é notada no ensino de diferentes disciplinas. Lembremos que o desenho, ainda no início da República, era apontado como uma técnica auxiliar no aprendizado da escrita, contribuindo no desenvolvimento da coordenação motora (BARBOSA, 2002). Mas não esqueçamos que para potencializar a memorização e a compreensão dos diversos conteúdos escolares são solicitados cartazes ilustrativos, história em quadrinhos, maquetes, audiovisuais, paródias, montagem de cenas teatrais etc. E qual a razão para utilizar a arte no aprendizado da Matemática, da Geografia, da História, da Língua Portuguesa, do Inglês ou das Ciências? Consideramos que o principal motivo está relacionado com a embriaguez inerente ao jogo da criação. Quando as pessoas estão envolvidas de “corpo inteiro' na realização de um trabalho artístico, as forças se intensificam e o auto-esquecimento se efetiva. Assim, compenetrados na realização de uma atividade artística, os alunos interagem com as matérias escolares de uma maneira mais plena se comparada aos momentos em que estão somente lendo e escrevendo. Esses momentos, de leitura e escrita, são essenciais. Contudo, o jogo da criação movimenta a "máquina inteira", isto é, mobiliza as emoções e sentimentos em conjunto com o raciocínio lógico e o pensamento verbal. Assim, a arte incita à busca de correlações entre palavras e conceitos com imagens, sons, paisagens, movimentos, personagens etc. Dessa forma, a relação entre arte e linguagem, no aprendizado dos conceitos científicos, pode contribuir tanto na memorização das informações, quanto na compreensão do conteúdo em foco, devido ao estabelecimento de correlações entre diferentes estímulos sensoriais com as palavras e os seus respectivos conceitos.

Até o momento, enfatizamos que o ensino das diferentes disciplinas escolares pode envolver a utilização da arte no decorrer do processo ou em uma parte específica dele. Nesse sentido, a arte potencializa o aprendizado dos conteúdos escolares porque envolve a intensificação da força e o auto-esquecimento na realização de atividades e porque constitui-se em um recurso valioso para os processos de memorização e compreensão. Pelas razões expostas, podemos 
destacar a finalidade da arte no ensino: ela intensifica a vida escolar - seja no fortalecimento ou enfraquecimento das valorações morais e nas horas de lazer, descanso ou confraternização - seja como recurso pedagógico no ensino das diversas disciplinas escolares. De agora em diante, discutiremos o papel do arteeducador e a especificidade do ensino da arte.

\section{O arte-educador e a especificidade do ensino da arte}

O arte-educador é o profissional que, no contexto escolar, tem como meta o planejamento, implementação e avaliação de intervenções artístico-pedagógicas que promovam o jogo da criação e a familiarização dos alunos com as diferentes tradições artísticas. Em um entendimento estrito, o arte-educador é o professor licenciado em uma das habilitações artísticas, como música, artes visuais, teatro ou dança, e que exerce esse ofício porque atende às exigências da legislação educacional vigente. Todavia, em uma perspectiva mais ampla, o arte-educador é aquele profissional que utiliza-se da arte para afetar as pessoas em uma comunidade ou grupo social. Por essa via de entendimento, o professor da Educação Infantil ou dos Anos Iniciais do Ensino Fundamental, com formação em Pedagogia ou Normal Superior, e que realiza intervenções artístico-pedagógicas com seus alunos, também está atuando como arte-educador.

Embora os professores com diferentes habilitações possam utilizar-se da arte como recurso pedagógico para ensinar valores e conteúdos escolares ou para intensificar as horas de descanso, lazer e confraternização, precisamos delimitar, de uma maneira objetiva, a especificidade do ensino da arte no contexto escolar. Para isso, retomamos a discussão acerca da cultura teórica proposta por Nietzsche (2007). Se a cultura teórica está relacionada com a ideia de que somente a razão pode conduzir os seres humanos na compreensão aprofundada da vida e do mundo e que, na modernidade, a ciência seria o campo de conhecimento no qual o pensamento lógico é aplicado com maior veemência, podemos especular que a escola, como uma instituição moderna, reflete parte ou totalmente os valores dessa cultura teórica. Como sabemos, a aprendizagem dos conceitos científicos é uma das 
principais metas do ensino escolar. Mas, se nossas proposições anteriores tiverem algum fundamento, podemos deduzir que a aprendizagem de conceitos científicos não se restringe ao crivo da razão. Assim, na teia de significados que construímos quando pensamos acerca da vida e do mundo, entrelaçam-se o pensamento lógicoverbal, a percepção, a imaginação e as emoções e sentimentos. Por isso, a arte tem sido utilizada como recurso pedagógico no ensino escolar: para que os alunos possam estabelecer correlações entre os conceitos científicos e as imagens, sons, movimentos, gestos etc. relacionados à vida e ao mundo.

A existência da arte no ensino escolar é concomitante ao surgimento da escola moderna. As finalidades, elencadas anteriormente, justificam a sua utilização nesse contexto. Contudo, para que a arte fosse aceita como uma área de conhecimento no ensino escolar e promovida à categoria de "disciplina", ou seja, para que ela figurasse como uma parte integrante da cultura teórica valorizada na modernidade, foi crucial a elaboração de um repertório de justificativas plausíveis por parte dos arte-educadores: a arte não é mero exercício escolar; também, não se restringe à reprodução de técnicas estereotipadas ou à livre-expressão; ela visa promover o desenvolvimento da criatividade e da sensibilidade estética por meio de métodos específicos e apropriados (BARBOSA, 1991; PORCHER, 1982).

No intuito de tornar a arte uma área de conhecimento, os movimentos de arteeducadores, na segunda metade do século $X X$, nos diferentes países como Estados Unidos, França e Brasil, reivindicaram a especificidade da arte como disciplina escolar. Para isso, foi imprescindível deslocar o fazer artístico da reprodução de técnicas estereotipadas, como os desenhos mimeografados, para a criação a partir da análise formal e simbólica da obra de artistas e tendências estéticas diversas. Também, a livre-expressão, desgastada pelo seu uso deturpado no decorrer das décadas, geralmente restringindo-se à prática do desenho livre, precisou ser suplantada por abordagens metodológicas as quais propuseram estratégias de intervenção pedagógica voltadas ao contexto escolar, ainda que, por vezes, embasando-se nos encaminhamentos metodológicos utilizados em museus. Assim, o ensino da arte, no contexto escolar, assumiu uma dupla função: fomentar a 
formação de um público consumidor e crítico de arte; e promover o jogo da criação por meio do estudo sistemático de diferentes tradições artísticas.

Mas as contingências de implementação do ensino da arte no contexto escolar nem sempre favoreceram a efetivação dessas duas funções. Conforme discutimos em outro momento (EYNG, 2011), a falta de professores licenciados prejudicou, durante décadas, o desdobramento em ações adequadas. Também, a constituição polivalente da disciplina, a qual visa integrar os conhecimentos das artes visuais, da música, do teatro e da dança, por vezes dificultou o trabalho pedagógico do arte-educador: como lecionar saberes e desenvolver práticas tão diversas se a formação universitária, de um modo geral, enfatiza a especificidade de cada modalidade artística?

Não temos uma resposta a essa questão. No entanto, gostaríamos de destacar os efeitos dessa polivalência. A incumbência de ministrar os conteúdos das diferentes modalidades artísticas tem gerado uma exacerbação das "aulas tagarelas", isto é, a centralização do ensino artístico na leitura e na escrita. llustraremos como as "aulas tagarelas" se manifestam com dois exemplos: o professor licenciado em artes visuais, mas que não domina os conteúdos musicais, trabalha um texto acerca da história da música e, dessa forma, atende às exigências curriculares; o professor licenciado em música, mas que não tem afinidade com o teatro, propõe um texto acerca do surgimento da tragédia e da comédia na Grécia para que seus alunos leiam, copiem e respondam um questionário. Mais uma vez, as normativas foram contempladas. Embora os exemplos citados sejam meramente ilustrativos e não correspondam à totalidade do trabalho artístico-pedagógico no contexto escolar, situações semelhantes acontecem diariamente em nossas escolas.

Consideramos que o pensamento de Nietzsche pode fornecer uma base teórica que permita compreender a relação entre arte, escola e ensino e, consequentemente, entre arte, ciência e linguagem, a partir de uma perspectiva trágica, ou seja, aquela que valoriza a arte como o grande estimulante da vida escolar. Por esse viés, torna-se pertinente investir no jogo da criação pedagógica na invenção de novas formas de ensinar e aprender arte na escola; e embriagar-se no jogo da criação artística a partir da compreensão de que as forças apolíneas da 
Criar Educação, Criciúma, v. 9, № 3, ago/dez. 2020 - PPGE - UNESC - ISSN 2317-2452

imagem e da palavra e as forças dionisíacas do som e do movimento são complementares nesse processo.

\section{Considerações finais}

No presente artigo discutimos a relação entre arte, escola e ensino a partir de reflexões subsidiadas no pensamento de Nietzsche. A obra desse filósofo possibilitou a abordagem dos seguintes temas: arte como criação, arte e linguagem, a finalidade da arte na educação e no ensino escolar e as especificidades do arteeducador e do ensino da arte no contexto escolar. No decorrer da nossa discussão recorremos ao repertório nietzschiano e às suas análises acerca da cultura grega. Assim, abordamos: as forças apolíneas e dionisíacas imbricadas no nascimento da teatro trágico; a noção de que a criação e a contemplação artísticas estão engendradas por uma condição fisiológica - a embriaguez -; e a distinção entre cultura teórica e cultura trágica. Ao pensar as implicações do pensamento do filósofo na análise das especificidades do ensino da arte no contexto escolar, consideramos que a concepção de cultura trágica do autor possibilita afirmar a arte como o grande estimulante da vida escolar.

Após atravessarmos esse caminho de discussões teóricas e suas implicações empíricas, gostaríamos de reinterpretar a parábola de Zaratustra sobre o camelo, o leão e a criança. Assim, consideramos que para o jogo da criação artística e pedagógica são necessárias as transmutações do espírito: sob a insígnia do "eu devo" - o espírito-camelo - reverenciemos a tradição, tanto no tocante à familiarização das novas gerações com as diferentes tradições artísticas, quanto nos apropriando de tradições artísticas e pedagógicas que contribuam na melhor qualificação do ensino da arte no contexto escolar; sob a insígnia do "eu quero" - o espírito-leão - pronunciemos um não à tradição da cultura teórica, que por vezes desvaloriza a arte, para que assim delimitemos, no tempo e espaço escolar, uma relação mais equiparada entre arte, ciência e linguagem; e sob a insígnia do "dizer sim à vida" - do espírito-criança - embriaguemo-nos no jogo da criação artística e 
Criar Educação, Criciúma, v. 9, no 3, ago/dez. 2020 - PPGE - UNESC - ISSN 2317-2452

pedagógica para que novos saberes e práticas possam tomar forma em nossas vidas.

\section{Referências}

ARISTÓTELES. A política. São Paulo: Editora Martin Claret, 2003.

BARBOSA, A. M. A imagem no ensino da arte. São Paulo: Perspectiva, 1991.

BARBOSA, A. M. Arte-educação no Brasil. São Paulo: Perspectiva, 2002.

EYNG, C. R. Arte - para quê? considerações sobre a finalidade do ensino da arte na escola. Educere et Educare - Revista de Educação 1ํㅗ semestre de 2011, vol. 6, ํㅡㄴ 11 , p. $79-91$.

NIETZSCHE, F. A gaia ciência. São Paulo: Companhia das Letras, 2012.

NIETZSCHE, F. Assim falou Zaratustra: um livro para todos e para ninguém. Porto Alegre: L\&PM, 2018.

NIETZSCHE, F. Crepúsculo dos ídolos, ou, como se filosofa com o martelo. Porto Alegre: L\&PM, 2017.

NIETZSCHE, F. Humano, demasiado humano. São Paulo: Companhia das Letras, 2005.

NIETZSCHE, F. O nascimento da tragédia ou helenismo e pessimismo. São Paulo: Companhia das Letras, 2007.

PLATÃO. A república. São Paulo: Editora Nova Cultural, 1997.

PORCHER, L. Educação artística: luxo ou necessidade? São Paulo: Cortez, 1982.

TADEU, T. Documentos de identidade: uma introdução às teorias do currículo.

Belo Horizonte: Autêntica, 2011.

Recebido junho de 2020 